\title{
Os conceitos de Povo e Plebe no Mundo Luso-Brasileiro Setecentista
}

The Concepts of People and Plebs

in Brazilian Old Regime (Eighteenth Century)

\section{Luisa Rauter Pereira}

Doutoranda em Ciência Política pelo Instituto Universitário de Pesquisas do Rio de Janeiro (IUPERJ-Rio de Janeiro ( Brasil) e professora substituta no Departamento de História da Universidade Federal de Uberlândia (UFU-Uberlândia / Brasil) e-mail: lurauter@terra.com.br

\section{Resumo}

No setecentos luso-brasileiro, assistimos ao progressivo desagregamento dos significados tradicionais do Antigo Regime Português: 1) o povo ou os povos como a totalidade de corpo político, os súditos ou vassalos, participantes de uma ordem de cunho místico cujo centro é o monarca; 2) o povo como os "mecânicos" ou o terceiro estado na sociedade de ordens. Tais significados são abalados pelas condições de uma sociedade colonial e escravista e pelas transformações rumo à modernidade que já ocorriam, ainda que timidamente. Neste movimento, a llustração e formas de contestação típicas do Antigo Regime português ganham peso, trazendo a idéia de que está nos povos a origem do poder. Além disso, a questão da plebe colonial se agrava, de modo que para muitos contemporâneos a colônia não possui um verdadeiro "povo" apto a participar do sistema político. Quem é o povo nos territórios coloniais passa crescentemente a ser um problema a ser solucionado ou uma aposta no futuro, desmantelando-se a estabilidade semântica de uma sociedade estamental.

\begin{abstract}
Brazil in the eighteenth century witnessed the gradual unbundling of the traditional meanings of the Portugal's Old Regime: 1 ) the people as the entire Political body participants of an order of mystic stamp whose center is the monarch 2) the people as the "mechanics" or the third state in the society of orders. These meanings are shaken by the conditions of a colonial slave society and the transformations towards modernity that has already occurred, though timidly. In this movement, Illustration and typical forms of contestation of the Portugal's Old Regime become more important, bringing the idea the source of power resides in the people. Moreover, the issue of colonial rabble gets worse, in a way that for many contemporaries the colony does not have a true "people" able to take place in the political system. The identity of the people in colonial territories becomes an increasing problem to be solved or a bet on the future, disrupting the semantic stability of an estate society.
\end{abstract}

\section{Palavras-chave}

liberalismo, vocabulário político, Império português, lluminismo, idéias políticas

\section{Keywords}

liberalism, political vocabulary, Portuguese Empire, Enlightenment, political ideas 


\section{Introdução}

0 conceito de povo ganhou lugar central no vocabulário político ocidental, tanto no campo da teoria política formal, quanto nos usos discursivos da prática política cotidiana. Refiro-me à idéia de soberania do povo ou dos povos posta em relevo pela ilustração nas últimas décadas do século XVIII e forjadora do discurso político contemporâneo. Este lugar proeminente obscurece em grande medida os usos e significados que teve o termo povo no mundo do Antigo Regime Português, assim como as peculiaridades que adquiriu nos primórdios da ilustração luso-brasileira. Questionar os significados que tiveram no passado os termos capitais que compõem nossa vivência política é algo que pode nos revelar camadas de significado esquecidas na linguagem política bem como compreender as raizes de nossa linguagem política atual.

0 século XVIII foi um período de intensos conflitos e negociações no espaço colonial entre as imposições de um Estado em processo de afirmação frente às formas tradicionais de organização e de repartição do poder na sociedade, o que se verifica, já nos primórdios do século, na guerra dos mascates em Pernambuco e nos diversos levantes na região das minas; é um momento em que as autoridades e grupos dominantes da sociedade colonial percebem com mais clareza as especificidades da população colonial, marcada pela escravidão, pela questão racial, e pela formação de uma população livre e pobre sem lugar estável no sistema produtivo; é o século da ilustração européia e do avanço da noção de "soberania dos povos", que se verificou, ainda que de forma mais acanhada, no espaço colonial.

Ao reunir fenômenos fundamentais, o período é palco de muitas controvérsias historiográficas. 0 olhar do observador e suas pré-concepções têm grande peso nas interpretações realizadas a respeito de um período conturbado como este. Implicados nas transformações postas em curso neste século, cientistas sociais e historiadores lançaram ao período olhares diversos. Desde a década de 1950 até a década de 1970, as análises foram marcadas pela idéia de "crise do sistema colonial e do Antigo Regime": um conjunto de amplas transformações mundiais que marcaria a ação dos atores específicos e sua linguagem política no espaço da colônia. Neste sentido, haveria ao longo do setecentos um processo de "tomada de consciência da situação colonial", e também de incorporação do ideário ilustrado europeu, que iria culminar no processo de independência nacional. Esta tomada de consciência seria forjada no embate entre interesses contrários relativos aos lugares sociais fundamentais do sistema, "colonos" e "colonizados". Nas últimas décadas, esta historiografia de viés marxista tem sido revista. Em lugar de enfatizar os interesses contrários de metrópole e colônia, têm se percebido o jogo de conflitos e negociações dentro das regras e modelos de pensamento de uma sociedade de Antigo Regime.

A visão de um movimento liberal e ilustrado que teria sido posto em marcha a partir de finais da segunda metade do século que se teria malogrado, especialmente em função da vinda da família real, tem sido bastante matizada. Concorreram nas Inconfidências e no movimento Pernambucano de 1817 uma série de tradições políticas e sociais típicas do mundo ibérico do Antigo Regime, para além do ideário ilustrado que pouca penetração teve na sociedade colonial.

Neste esforço de revisão é preciso aprofundar a investigação histórica dos termos e conceitos que se tornaram centrais no pensamento político 
Formadas por um conselho de dois a seis vereadores, dois juizes ordinários um procurador os "oficiais" - e por uma série de funcionários subalternos, como os fiscais de obras públicas, os escrivães e os juizes de órfãos, as câmaras eram os órgãos de administração, mas também de "representação" política do "povo" ou dos "povos" da colônia frente ao rei. A escolha dos oficiais e funcionários era feita "por uma assembléia de todos os chefes de família abastados e respeitáveis habilitados a votar". As câmaras se reportavam ao Conselho Ultramarino em Portugal através de "petições", que eram respondidas em nome da vontade do monarca. As petições eram vistas como um direito dos povos, mas seu acatamento era uma escolha real.

Ordenações Afonsinas. Livro I. Lisboa: Fundação Calouste Gulbenkian, 1984. p.4.

Ordenações Manoelinas. Livro I. Fundação Calouste Gulbenkian, 1984. p.1.

4

XAVIER, Ângela Barreto e HESPANHA, António Manuel. A Representação da Sociedade e do Poder. Paradigmas Políticos e Tradições Literárias. In. HESPANHA, A. M. (coord.). História de Portugal. Vol. 4. 0 Antigo Regime. Lisboa: E. Estampa, 1993. contemporâneo, abordando momentos anteriores em que não tinham o mesmo significado e peso conceitual da atualidade. Desta forma, se pode contribuir para o esforço de desnaturalização da linguagem política atual, atentando para sua historicidade. Além de evitar anacronismos na interpretação histórica, este tipo de investigação pode revelar camadas de significado que compõem o cânon da semântica política moderna.

\section{0 Povo e os Povos como totalidade do corpo político}

0 povo como totalidade do corpo político, embora compareça nos documentos do século XVIII, concorre com outros também muito presentes, como o conjunto dos "vassalos" ou "súditos", "comunidade" ou "Reino". 0 povo ainda não tem neste momento o peso que passará a ganhar no mundo liberal embora isso não signifique que tem pouca importância no léxico político setecentista luso-brasileiro. "Felicidade", "conservação", "sossego" dos povos eram, por exemplo, as justificativas constantes para as resoluções das câmaras municipais, bem como para os pedidos feitos à administração lisboeta ${ }^{1}$.

As Ordenações portuguesas, textos legais que regeram a nação portuguesa desde meados do século XV até os primórdios século XIX podem nos dar indicações importantes a respeito desta antiga tradição. Dentre estas, podemos citar as Ordenações Afonsinas, pois são o alicerce de todos os textos posteriores. Trata-se de uma sistematização escrita dos costumes e leis vigentes no reino luso, o direito natural ou das gentes. Em suas palavras iniciais, o texto lembra "o grande louvor que o Estado Real consegue por bem da justiça (...), que não é achada entre todas as virtudes alguma tão louvada, nem de tão grande preço como a justiça; porque ela só é a que tolhe todo pecado, e maldade e ainda conserva cada um em seu verdadeiro ser, dando-Ihe o que seu é diretamente". 0 rei deve ser sábio para subjugar seus apetites mentais e desejos carnais ao jugo da razão para diretamente "reger seu Reino, e senhorio, e manter seu povo em direito, e justiça (...)" 2. Logo, "assim se deve fazer o bom Príncipe, pois que por Deus foi dado [seu poder] principalmente não para si, nem seu particular proveito, mas para bem governar o seu povo, e aproveitar a seus súditos como a próprios filhos"3.

Nas Ordenações, vemos que o "povo" é associado à idéia de justiça e à relação com o monarca. Este é o detentor da soberania, mas deve governar de forma justa, o que na lógica de uma sociedade de Antigo Regime significava fundamentalmente manter as distinções sociais, os lugares específicos, as funções e privilégios dos corpos componentes da sociedade, isto é, os povos.

Antonio Manuel Hespanha sistematizou muito bem esta concepção 4 . Para este autor, o povo é visto na tradição "corporativa" portuguesa como um elemento integrante de uma ordem universal dirigida por um destino místico comum. Cada uma destas partes tem uma função especifica e indispensável a desempenhar na garantia da harmonia e na caminhada rumo a um telos. Disso se depreende que o poder é visto como algo necessariamente repartido: cada parte possui uma determinada jurisdição que o rei deve respeitar e manter sob pena da desagregação do todo social. Trata-se de uma visão plural do poder: a figura real deve acatar as diversas jurisdições existentes, atribuindo a cada parte o que lhe é próprio por direito, mantendo assim a harmonia, a paz e realizando a justiça, considerada o fim supremo da política humana. 0 poder real é visto como algo limitado, tendo que respeitar os poderes tradicionais dos diveros membros que compoem o corpo social, realizando assim seu pricipal dever: realizar a justiça, resolver os conflitos, fazer valer o direito que preexiste às vontades e paixões humanas. 
Infelizmente não pudemos ter acesso ao

Tractado analytico e apologético sobre os provimentos dos bispados da coroa de Portugal: calumnias de castella convencidas: resposta ao seu author D. Francisco Ramos del Manzano: justifica-se o procedimento do senhor Rey $D$. Joam o IV e do senhor Rey D. Affonso seu filho, com a fé apostólica (...) escrita em 1715 por Manuel Rodrigues Leitão (Lisboa: Officina Real Des/andesiana, 1715. Esta obra é citada por Antônio Manuel Hespanha como um exemplo do "paradigma corporativo"

6

SOUZA, lara Lis Carvalho. Pátria Coroada. 0 Brasil como corpo político autônomo (17801831). São Paulo: Fundação Editora UNESP, 1999

7

CAMPOS, Francisco Antônio de Novaes. Príncipe Perfeito. Emblemas de D. João de Solórzano. Lisboa: Instituto de Cultura e Lingua Portuguesa, 1985.

Segundo E. Kantorowicz, "A doutrina da teologia e do direito canônico, que ensina que a Igreja e a sociedade cristã em geral são um corpo místico, da qual a cabeça é o Cristo foi transposta pelos juristas da esfera teológica àquela do estado, do qual a cabeça é o rei". KANTOROWICZ, Ernst. Les Deux corps du roi: essai sur la théologie politique au Moyen âge. Paris: Gallimard, 1989.

9

No original: "Fe o Povo fórma o Corpo/ o Rey Cabeça/ Os fentidos trazer deve apurados/ Para $q \sim$ prompto o firva e the obedeça/ Por todos vêlle em fim com mil cuidados, / Q'fó por q tantos poderes the fão dados". KANTOROWICZ, Ernst. Op.Cit.

10

Ibidem. p.663.
De toda esta explanação, devemos apreender que conceito de povo e de povos deve ser entendido no âmbito de uma idéia de pacto: dos vassalos era esperada a lealdade e a defesa da soberania portuguesa nos territórios e do rei era esperado que fosse virtuoso, agisse com justiça, o que siginificava na lógica do Antigo Regime repeitar os direitos das diversas partes que compoem a sociedade - os povos representados nas câmaras. Porém, este pacto não deve ser compreendido simplesmente como o resultado de uma ação voluntária realizada por indivíduos autônomos, no plano lógico ou em algum momento da história, que fundaria a sociedade, a política e 0 direito. Trata-se de um pacto entre os homens, ou melhor, entre os corpos da sociedade mas sempre referido a uma ordem superior que deve ser respeitada, que o torna possivel e the dá sentido.

Diversas obras influêntes no século XVIII clarificam esta concepção básica que informa a semântica e o lugar do "povo" na política. Faremos uma breve exposição de algumas delas, lembrando-nos sempre que a letra da doutrina não expressa diretamente a vivência do cotidiano político de uma dada época e lugar, embora possa nos esclarecer sobre muitos de seus pontos. Em todo o setecentos português, muitos tratadistas escreveram obras em que teorizaram a respeito da relação entre o rei e seus vassalos ${ }^{5}$. Muitas delas faziam parte da antiga tradição dos "espelhos de príncipes" 6 obras destinadas a dar aos reis ensinamentos de virtude e de bom governo através de exemplos históricos, argumentos de razão e autoridade. 0 final do século foi particularmente profícuo nestas obras, tanto pelos defensores das reformas ilustradas, quanto dos defensores da tradição política do Antigo Regime, interessados em influenciar de algum modo a monarquia.

Uma destas obras foi o Príncipe Perfeito de 1790, escrita por Francisco António de Novaes Campos ${ }^{7}$. 0 autor, formado em Leis em Coimbra em 1759, parafrasea neste livro do autor espanhól Solórzano Pereira, cuja obra data do século XVII. 0 Principe Perfeito procura lembrar à Dom João VI seu dever moral ante Deus e seu povo. Em sua argumentação, a segurança e harmonia do corpo social vem da relação entre Deus e o Rei. Este não é absoluto, pois é julgado por Deus em seus atos, devendo agir com justiça. Em relação ao seu povo, o corpo social, o rei é a cabeça8:
Se o povo forma o Corpo, o Rey Cabeça
Os sentidos trazer deve apurados
Para que pronto o sirva, e lhe obedeça
Por todos vele em fim com mil cuidados
Que só por que nenhum dos seus pereça,
É que tantos poderes lhe são dados 9

Segundo esta metáfora do corpo humano que "impregnou o pensamento político desde o final da Idade Média" ${ }^{10}$, ser a cabeça não significa ser absoluto nesta tradição. Significa, em primeiro lugar ser um centro moral que sirva de espelho ao resto do corpo social, o que contribui para a manutenção da ordem e harmonia.. Seus poderes Ihe foram dados por Deus para que cuide de seu povo, entendido como o conjunto dos súditos ou vassalos, como um pastor cuida do seu rebanho, punindo quando necessário. Deve dar "franca entrada" aos povos, ouvindo as "queixas dos vassalos" e "administrar com justiça", dando a cada um o que lhe é próprio.

Outra obra importante foi a Dissertação a favor da monarquia escrita pelo Marquês de Penalva em 1799. Seu autor, um nobre da melhor tradição do reino, neto de um guerreiro da Restauração portuguesa concluída em 
11

PENALVA, Marquês de. Dissertação a favor da Monarquia. Porto: Edições Gama, sd. (Titulo original: Dissertação a favor da Monarquia. Onde fe prova pela razão, authoridade, e experiencia fer efte o melhor e mais jufto de todos os Governos; e que os noffos Reis são os mais absolutos, e legítimos Senhores de Feus Reinos: offerecida a sua alteza Real o Príncipe do Brazil nosso senhor pelo Marquez de Penalva. Lisboa: na Regia officina Typografica. M. DCC. XCIX, por ordem de sua magestade)

12

PENALVA, Marquês de. Op.Cit. p.47.

13

Ibidem. p.76.
1640 - o segundo Conde de Vila-Maior e primeiro Marquês de Alegrete -, foi governador da capitania de São Paulo e do Rio Grande no Reinado de Dona Maria Primeira.

A obra é uma defesa da legitimidade da monarquia portuguesa e das hierarquias do Antigo Regime frente ao contratualismo, às noções de igualdade e direitos do homem. A monarquia, a soberania de um só, é vista como o melhor dos regimes, pois é natural e necessária como a autoridade que um pai tem em relação aos seus filhos. A metáfora do pai e filhos é de ampla utlização no periodo para tratar da relação entre rei e vassalos: os reis são "os Pais e Pastores dos Povos". Segundo Penalva,

cederam a este pai comum [o Soberano] todos os pais de familias e seus veneráveis direitos, e encarregou-se a um só o governo de todos. Sentiram-se logo os benignos influxos que a concórdia produz: união de forças, igualdade de subordinação, semelhança de costumes, interesse reciprocro; tudo concorreu para fazer o Patriotismo, uma das mais belas e necessárias qualidades de Cidadão e Vassalo ${ }^{11}$

Embora o monarca seja o titular único da soberania, isso não significa em absoluto que no regime monárquico não haja liberdade e direitos do "cidadão". Para Penalva, a monarquia difere radicalmente do despotismo, pois os cidadãos possuem direitos que podem ser exigidos, o que se verificaria de forma peculiar na pátria portuguesa onde o soberano consente que sejam julgadas as causas entre a coroa e os seus Vassalos (...) tanto é o respeito que os nossos Príncipes tem a Deus por quem reinam, e à justiça e observancia das mesmas leis!" 12

Da mesma forma, para Penalva, a igualdade também existe na monarquia. Tal como pai de família, o monarca "distingue e paga os seus serviços, mas sem ofensa do direito que têm a ser ouvidos e protegidos com igualdade" 13 . Toda esta argumentação se dirige a provar que a argumentação dos "inquietos" ilustrados contra o antigo regime não possui fundamento, pois neste, há todas as garantias aos povos e limites ao alcance do poder real. 0 poder absoluto legítimo e justo não significaria despotismo, pois possui uma "jurisdição verdadeiramente real que não pode ser extendida para além de certos limites ditados pela "Constituição".

Como então provar esta legitimidade? Historicamente a leigitimidade do dominio dos Príncipes portugueses pode ser provada, primeiro, pelo direito de propriedade adquirido por doação feita pelo Rei Espanhol ao Conde D. Henrique e por conquista em guerra justa - a expulsão dos "maometanos" do território. Estes fatos fundadores confeririam ao rei pelas leis do resgate e pela gratidão "a sujeição dos Povos libertados" da opressão. Além disso, a celebração das Côrtes de Lamego, a primeira reunião das Cortes Portuguesas, cujo acontecimento sempre fora motivo de dúvidas, seria uma prova de que a monarquia era, além de fruto de conquista e doação, consequencia da "livre escolha dos Povos".

0 argumento da livre escolha através da tradicional instituição das cortes difere de longe do argumento de que a soberania é fruto de um contrato ou pacto originário entre os homens, entendidos como indivíduos autônomos. As Côrtes representavam simplesmente o momento em que o rei ouvia seus vassalos,

à imitação dos Pais que chamam seus filhos crescidos para de comum acordo alterarem alguma coisa na família, assim os nossos soberanos chamavam os Procuradores dos povos para lhes manifestar as circunstancias imperiosas, que os 

Rebeldes. Violência coletiva nas minas na primeira metade do século XVIII. Belo Horizonte: Editora c/ Arte, 1988. p.34

\section{6}

Carta Regia de 04 de março de 1716. APM. Seção Colonial. Códice SG 04 fls 129 e 130. Apud. ANASTASIA, Carla Maria Junho. Vassalos Rebeldes. Violência coletiva nas minas na primeira metade do século XVIII. Belo Horizonte: Editora c/ Arte, 1988.

\section{7}

Discurso Histórico e Politico sobre a Sublevação que houve nas Minas no ano de 1720. Belo Horizonte: Fundação João Pinheiro, 1994. p.72.

18

Ibidem. p.68. obrigavam a dispensar algumas das leis fundamentais, ficando-Ihes com o seu voto um penhor da sua aprovação, e obediência 14

Esta conceituação aparece também nos episódios conflituosos opondo os "povos"e as autoridades metropolitanas, por exemplo nas rebeliões ocorridas na região mineradora no inicio do século. Eram os povos que buscavam a preservação de seus antigos direitos e privilégios pactuados ou costumeiramente assegurados, que estavam sendo ameaçados pela administração real. Deste era esperado que fizesse a justiça e a paz, o que significava fundamentalmente o respeito e manutenção dos lugares sociais e privilégios estabelecidos. Na colônia, estes direitos decorriam em grande medida dos direitos adquiridos pelos "povos" em decorrência da conquista e defesa do território, o que garantia a soberania portuguesa nas regiões coloniais.

Segundo Carla Maria Junho Anastasia,

$$
\begin{aligned}
& \text { estas revoltas explicitavam a dificuldade que tinham as autoridades em impor } \\
& \text { regras sem respeitar aquelas estabelecidas no convivio da comunidade. Foram } \\
& \text { revoltas claramente reativas, nas quais os mineradores não pretendiam colocar em } \\
& \text { xeque as regras estipuladas para o jogo colonial, mas tão somente lutavam para } \\
& \text { garantir a manutenção de determinados procedimentos inaugurados no alvorecer } \\
& \text { das minas, e, em geral, considerados razoáveis pela sua população } 15
\end{aligned}
$$

Anastasia, ao analisar um levante ocorrido em 1715 conclui que os revoltosos não discutiam a justiça do pagamento do tributo cobrado pelos representantes do rei, mas apenas a pretendida mudança em sua forma. Em outras palavras, não discutiam sua fidelidade ao rei e seu direito soberano sobre o território e as gentes. 0 rei terminou por ceder às pressões à pedido do governador D. Bras, e concedeu perdão aos revoltosos a fim de "sossegar esses povos com deixar de executar as ordens para se cobrarem os quintos por bateias (...) permitindo em que se contituasse com a forma estabelecida e assentada com os povos em trinta arrobas de ouro por ano (...)" 16.

No grande levante de 1720, conhecido pelo nome de um dos seus líderes, Felipe dos Santos, este significado é reiterado. De cordo com uma das fontes mais importantes referentes ao movimento, supostamente escrita pelo então governador, o Conde de Assumar, entre os intentos dos povos estava a "conservação do respeito" por parte daqueles que "se tinham antigamente apoderado da autoridade e mando de que hoje se achavam destituídos, e o procuravam por meio tão ilícito recobrar" 17. Eram os povos que buscavam a preservação de seus antigos direitos e privilégios pactuados ou costumeiramente assegurados, que estavam sendo ameaçados pelo poder real. Estes, dizia conde, "querem que a lei seja conforme eles vivem, e não querem viver eles conforme a lei".18

Estes movimentos ocorridos na primeira metade do século XVIII, dos quais expusemos um exemplo das Minas, demonstram a força na colônia da tradição de relação entre "povos" e "monarca". Deste era esperado que fizesse a justiça e a paz, o que significava fundamentalmente o respeito e manutenção dos lugares sociais e privilégios estabelecidos. Na colônia, estes direitos decorriam em grande medida dos direitos adquiridos pelos "povos" em decorrência da conquista e defesa do território, o que garantia a soberania portuguesa nas regiões coloniais.

Em outros casos, os conflitos podiam trazer uma radicalização do pacto entre povos e rei e uma conceituação diferente do povo. Na famosa 
19

Narração Histórica das Calamidades de Pernambuco sucedidas desde o anno de 1707 até 1715 com a notícia do Levante dos Povos de suas capitanias. Escrita por um anônimo (1749). Revista do Instituto Histórico e Geográfico Brasileiro, n.53, Parte II, 1890.

20

Ibidem. p.139
"Guerra dos Mascates" no início do século, os povos não eram apenas os participantes de uma ordem mística, mas os integrantes de um verdadeiro "pacto" ou "contrato" com o rei. Sendo este pacto quebrado, por tirania real, isto é, pela não observância da obrigação de fazer a justiça, aos povos cabia o direito de rebelarem-se. Isto é possivel por que nesta concepção a justiça é "reta e igualmente distribuída", de modo que todos os membros da comunidade política tem o direito e o dever de, por todos os meios, procurar mantê-la. Esta noção pactual radicalizada, é bom que se entenda, não foge ao corporativismo que regia a visão tradicional da sociedade e da política. 0 pacto entre povos e rei só se legitima por que é ancorado num ordenamento natural, costumeiro e de cunho divino.

No episódio em questão, a guerra foi travada pois a nobreza da terra defendia o monopólio da representação política na Câmara de Olinda sob o argumento de que seus antepassados tinham conquistado a capitania aos índios no século XVI e a reconquistado aos holandeses no século XVII, restaurando a soberania portuguesa na região. Este argumento, que fez história nos movimentos em Pernambuco até 1824, fica claramente exposto num célebre trecho de uma carta atribuída na Narração Histórica à um membro da nobreza:

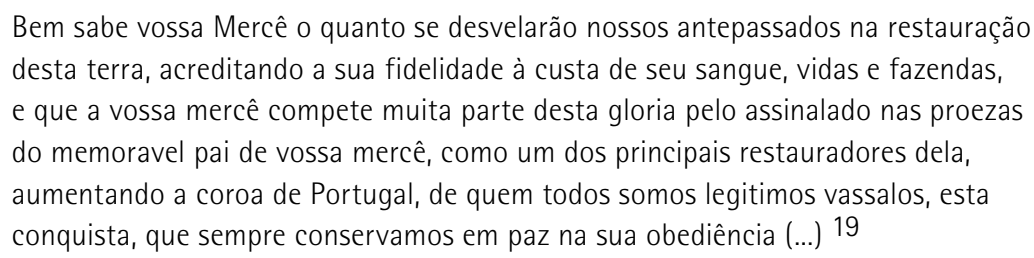

Em resposta ao governador da Paraíba que havia enviado à nobreza pernambucana um manifesto em 18 de Julho de 1711 condenando o levante, a nobreza se refere à tradicional relação entre os povos e o monarca, recordando que "a obrigação do rei e dos seus ministros é conservar os vassalos e suditos em paz, fazendo observar a cada um os ditames da razão e justiça". Porém, continua, "como a justiça divina é só reta e igualmente distributiva, permite algumas vezes superiormente, que os mesmos que reconhecem a obediencia castiguem as tiranias, mostrando rebeldia (...)". 20

Esta concepção radicalizada teve paralelo no plano doutrinário, embora seja difícil determinar o quanto estas obras tinham influência nos eventos descritos. A restauração portuguesa de 1640 havia trazido novos elementos para o conceito. Era preciso, após 60 anos de domínio dinástico espanhol, fundamentar o direito do reino português de rebelar-se e retomar sua soberania. Neste contexto, o argumento da escolha livre dos povos, que já fazia parte do repertório tradicional legitimador da soberania real, ganhou relevo e proeminência. Era certo ainda que a sucessão dinástica, a conquista e adoção tinham sua importância na determinação do poder soberano, mas para que a soberania de fato fosse conferida era imprescindivel o consentimento dos povos, entendidos aqui como o conjunto dos três estados ou ordens. Em meados do século XVII, Francisco Velasco Gouveia escreveu um tratado analítico defendendo a justiça e legitimidade da aclamação de D João IV. Portugal acabara de sair da dominação da coroa Espanhola e era necessário justificar perante as nações cristãs e a igreja católica a sublevação que culminara com a aclamação do Duque de Bragança D. João. A primeira parte se dedica a mostrar que o reino de Portugal tem o poder para aclamar rei quem tiver esse direito e expulsar 
21

Justa Acclamação do Sereníssimo rey de Portugal D. João o IV. Tratacdo analytico dividido em três partes. Ordenado e divulgado em nome do mesmo reyno, em justificação de sua acção. Dirigido ao summo pontífice da Igreja Cathólica, Reys, Principes, respublicas, e senhores soberanos da Christandade. Composto pelo Doutor Francisco Velasco Gouveia (...). À custa dos três Estados do Reyno. Lisboa, Typ. Fênix Beco de Santa Martha, n. 123, 1846.

22

Ibidem. p.48

23

Esta transformação semântica, entretanto, não eliminou o peso da tradição hierárquica, de modo que, tanto o governo pombalino quanto os governos mariano e joanino, tiveram que dialogar com os diversos poderes estamentais e incorporar suas reivindicações e visões de mundo. Segundo Ana Rosa Cloclet da Silva, a política iniciada no governo de Pombal teve franca participação de elementos tradicionais, como a Igreja, e foi obrigada a abrir espaço à nobreza descontente, especialmente no periodo conhecido como a "viradeira". Ver: SILVA, Ana Rosa Cloclet da. Inventando a Nação: Intelectuais Ilustrados e estadistas lusobrasileiros na Crise do Antigo Regime Português (1750-1822). São Paulo: Hucitec: FAPESP, 2006.

24

BICALHO, Maria Fernada. 0 que significava ser cidadão nos tempos coloniais. In. ABREU, Martha e SOIHET, Rachel. (orgs). Ensino de História. Conceitos, Temáticas e Metodologia. Rio de Janeiro: Casa da Palavra, 2003.

25

SERRÃO, José Vicente. Sistema Político e Funcionamento Institucional do Pombalismo. In. MONTEIRO, Nuno Gonçalo et ali (orgs.). Do Antigo Regime ao liberalismo (1750-1850). Lisboa: Ed. Veja, sd. aquele que não o tiver. Para Velasco Gouveia, o fundamento desse direito é que "o poder regio dos reis está nos povos e Repúblicas, e delas o receberam imediatamente" 21. Todo o poder existente no mundo dos homens vem de Deus, é verdade, mas sua existência se destina à conservação humana, de modo que a "razão natural" diz que este poder foi dado à todos os homens da comunidade, ao reino, enfim, aos "povos".

Nesta concepção, portanto, o rei recebe o poder não diretamente de Deus, como queriam muitos teóricos do periodo, mas com a mediação dos povos e através de um "pacto" cuja "condição" é a de que os povos sejam governados e administrados com justiça. Porém, esta transferência de poder que origina a soberania real não implica que os povos fiquem absolutamente desprovidos do poder. Citando São Tomaz de Aquino, Gouveia argumenta que de acordo com o "direito natural", na República, assim como entre os particulares, não pode haver renuncia total ao poder para autoconservar-se. Em outras palavras, assim como um indivíduo pode rebelar-se e usar de violência para manter sua vida, as comunidades também o podem. Isto porque, embora os povos transfiram o poder aos reis, este Ihes fica "habitualmente" e pode ser reassumido "quando Ihes for necessário para sua conservação". A autor salienta que esta possibilidade se restringe.

\footnotetext{
somente nos casos particulares (que raramente acontecem) dos Reys convertem o governo justo do povo, em tirania, abusando do que os mesmos povos thes transferiram; ou de serem intrusos, sem lhes pertencer o direito do reino; podem os povos uzar do poder, que in habitu lhes ficou, e reduzi-lo a acto, tratanto de sua natural defesa e remedio 22
}

A política pombalina posta em ação a partir da segunda metade do século pode ser entendida justamente como uma reação a visão corporativa do povo e de sua relação com o poder real. A lei, em autores "pombalinos" como Tomáz Antônio Gonzaga, depende da vontade do legislador e não, de forma alguma, da aceitação do povo. Os privilégios são apenas leis particulares e sua validade não vem do costume, das tradições ou da emanação popular, mas, como em qualquer outro caso, provém do reconhecimento que the dá ou não o monarca. No que toca ao nosso ponto, o lugar e a função do povo na linguagem política, importa perceber que o espírito fundamental do pombalismo transforma os "povos", que na tradição eram identificados a um conjunto de vassalos detentores de direitos e jurisdições, em algo próximo a indivíduos súditos horizontalmente submetidos a uma lei comum 23 .

Na visão dos contemporâneos, o projeto pombalino foi um conjunto de ações no sentido de modernizar o Império Português a partir da ação decisiva do rei, o que pode ser entendido contemporaneamente também como a ação do Estado. É criada uma verdadeira burocracia num sentido mais próximo ao moderno: um conjunto de funcionários que respondem diretamente à autoridade real, no sentido de enfraquecer a tradional administração organizada nos moldes do Antigo Regime, isto é, através da concessão real de mercês, honras e privilégios ${ }^{24}$. Como vimos, na tradição lusitana, o poder era essecialmente repartido, de modo que estes "cargos" significavam para os nobres a concessão de poderes e jurisdições em nivel local, embora vinculados à manutenção da soberania portuguesa em seus territórios. Com as mudanças, os órgãos institucionais da coroa e seus funcionários ganharam mais prestígio social e passaram a ser pagos com salários, o que se opunha a tradição de tomar os cargos por bens particulares e transmissiveis por 
DIAS, J. S da Silva. Pombalismo e Teoria Política. Cultura, História e Filosofia. Vol 1. Instituto Nacional de Investigação Científica. Centro de História da Cultura da Universidade Nova Lisboa, 1982. hereditariedade. ${ }^{25}$ Era preciso, frente à crise econômica por que passava o Império, transformar o Estado numa entidade com mais poder frente à sociedade, dotando-o de uma administração mais eficiente.

No plano dos grandes textos fundamentadores do projeto pombalino, podemos definir duas grandes vertentes, de acordo com o estudo de J. S. Da Silva Dias 26: um grupo que se apoia no argumento do direito divino dos reis e outro no discurso jusnaturalista. Dois autores se destacam no primeiro grupo: Pereira de Figueiredo; que publica em 1766 a Tentativa Teológica e em 1769 a Demonstração Teológica; e José Seabra da Silva, com sua Dedução Cronológica e Analítica em 1768.

Estas obras se batiam contra a visão sacral da sociedade, isto é, contra a concepção da sociedade e do Estado como um braço secular da Igreja. 0 poder é emanado diretamente de Deus ao rei sem passar pela mediação da Igreja romana e dos corpos da nação reunidos nas cortes. A única limitação da autoridade regia é a vontade de Deus. Contra as doutrinas pactistas, defendem que a monarquia portuguesa é "pura", no sentido de autônoma frente a qualquer outro poder, igreja e povos, pois não nasceu de um pacto, sendo as cortes órgãos conjunturais e consultivos. A soberania portuguesa teria sido o fruto de uma conquista obtida em gerra justa contra os infiéis, doação e concessão e não por eleição dos povos reunidos nas cortes de Lamego como na visão pactual.

A justificação jusnaturalista teve seu lugar em autores "pombalinos". Porém o jusnaturalismo propriamente moderno, teve pouca inserção até os anos 70, quando então começa a ter alguma representatividade. No Brasil, o maior nome foi ironicamente o de Thomaz Antônio Gonzaga, o futuro inconfidente Mineiro de 1789. Não era propriamente um autor "brasileiro", uma vez que não se pode ainda falar num mundo intelectual autônomo na colônia. Nascido na cidade portuguesa, teve pai brasileiro e mãe portuguesa, tendo se mudado para o Brasil em 1751, onde fez seus primeiros estudos. Como muitos filhos da elite "brasileira", ingressou na Universidade de Coimbra em 1761 onde sete anos depois se formou bacharel. Voltando ao Brasil, em 1782, foi nomeado Ouvidor dos Defuntos e Ausentes da capital da capitania de Minas Gerais, Vila Rica.

Ainda em Portugal escreveu o Tratado de Direito Natural, tese apresentada com a intenção de tornar-se docente na Universidade em que se formou. Neste texto, nos apresenta o jusnaturalismo possivel na sociedade portuguesa naquele momento: ancorado nos parâmetros da teologia, do direito canônico e do jusnaturalismo tradicional. Por direito natural, Gonzaga entende "a coleção de leis que Deus infundiu no homem para conduzir ao fim que se propôs na sua criação". Estas leis levaram os homens a organizarem-se em sociedade, isto é, a postarem-se sob um império e unirem-se por pactos para assegurarem sua segurança e tranquilidade.

Segundo Gonzaga, apoiado nas sagradas escrituras, todo o poder que um homem pode exercer sobre seus semelhantes tem origem divina, logo, o rei só pode ser julgado por Deus. 0 problema é saber se chega ao rei com algum tipo de mediação, a que Gonzaga responde negativamente: não é verdade que o poder estava no povo e esse o transferiu no ato da "eleição" (entendido como escolha); o povo não tem em si poder algum, mas somente a faculdade da eleição de quem receberá o poder. 0 povo dá origem à sociedade, mas apenas escolhe a forma de governo e "elege" aqueles que irão exercitar o império. 
27

GONZAGA, Tomaz Antonio. Tratado de Direito Natural. São Paulo: Martins Fontes, 2004. p.147.

28

FLECK, Eliane Cristina Deckmann. Os Inconfidentes - Intérpretes do Brasil. In: AXT, Günter e SHULER, Fernando. Intérpretes do Brasil. Cultura e Identidade. Porto Alegre: Artes e Ofícios, 2004. p.10.

29

MELLO, Evaldo. C. de. Rubro Veio - o imaginário da restauração pernambucana. $2^{\text {a }} \mathrm{ed}$. Rio de Janeiro: Topbooks, 1997.

30

MOTA, Carlos Guilherme. Nordeste 1817: Estruturas e Argumentos. São Paulo: Perspectiva, 1972.
Não há, para Gonzaga, contrato algum em que o monarca deva prestar contas ao povo. Portanto, "o rei não pode ser de forma alguma subordinado ao povo; e por isso ainda que o rei governe mal e cometa algum delito, nem por isso o povo se pode armar de castigos contra ele"27. Ao povo, depois que o elegeu, "já nada mais toca do que obedecer-lhe e respeitá-lo. Sua alegação se opõe, não somente ao direito natural de extração laica, mas também às teorias pactistas da segunda escolástica ibérica que postulavam o povo como a origem da soberania real e a possibilidade de que, em caso de despotismo, este poderia retomar para si a soberania e se rebelar contra o rei. Este pactismo ganhava relevo num momento em que o despotismo sufocava as colônias e muitos teóricos, como Gonzaga, apoiados pelo governo, procuraram combatê-la.

Ao final do XVIII, conjurações em Minas Gerais (1789), Rio de Janeiro (1794) e Bahia (1798) criticaram o que viam como o "despotismo" pombalino e trouxeram novas conceituações do povo. Os princípios do direito natural iluminista, reforçados pelo exemplo das revoluções na América e França, forneciam aos conjurados novas ferramentas críticas, notadamente a idéia de liberdade, igualdade e soberania dos povos ou do povo. Estas se somavam à tradição ibérica do governo justo e da crítica à tirania.

0 impacto das idéias propriamente liberais foi diferenciado em cada movimento, e, sobretudo, não deve ser sobrevalorizado. Foi mais importante no caso carioca e baiano e menos nas minas. Os conspiradores mineiros, embora tenham sido tocados pelas idéias ilustradas permaneciam fortemente imersos no mundo do Antigo Regime. Sua concepção do governo justo contraposto à tirania atrelava-se não ao pressuposto da igualdade entre cidadãos, mas ao dever do governante de respeitar e manter as hierarquias e privilégios dos estratos da sociedade. De fato, os inconfidentes falavam em "liberdade", "república", mas, ao contrário da imagem que se cristalizou na memória nacional, não foram o prenúncio de um republicanismo liberal no Brasil. 0 termo "república", tal como aparece nos textos coloniais, significava, não um regime político específico, mas qualquer organização política. A defesa da liberdade, por seu turno, e o conseqüente desejo de romper com o pacto colonial expresso pelos conjurados das minas faziam parte de concepções tradicionais já expressas em outros movimentos nas Minas no século XVIII: manter a justiça, as dignidades nobres eliminando "os constrangimentos que impediam a fruição tradicional de direitos"28. Logo, ao falar em "povo" ou "povos", não era à "soberania popular" à que se referiam ou a um governo representativo no sentido liberal.

No movimento revolucionário pernambucano de 1817, da mesma forma, ao jusnaturalismo iluminista uniram-se mais uma vez as concepções tradicionais da vassalagem e do pacto ou contrato entre súditos e o rei. Ao "povo pernambucano", caberiam privilégios e liberdades pela lealdade prestada ao rei por ocasião da grande obra da expulsão dos holandeses no século XVII. ${ }^{29} 0$ movimento revolucionário de 1817, portanto, não pode ser definido apenas como um conflito diretamente ligado à "situação colonial" opondo colonizadores e colonizados, aristocracia rural e mercadores coloniais portugueses, como sugeriu Carlos Guilherme Mota ${ }^{30}$. Não se tratava de um movimento liberal emancipacionista e anti-colonialista. Os rebeldes justificavam a rebelião com argumentos típicos da tradição ibérica de crítica ao despotismo em nome dos "povos". 
31

A frase foi tida como um marco pela historiografia interessada em entender o processo de tomada de consciência da situação colonial, que teria contribuídos para os movimentos liberais do final do século XVIII e para a independência

32

VILHENA, Luiz dos Santos. Recopilação de Noticias Soteropolitanas e Brazílicas. Bahia: Imprensa Official do Estado, 1921. p.140.

33

Ibidem. p.44.

34

Ibidem.

35

Ibidem. p.47

36

Ibidem. p.46.

\section{0 povo como o terceiro estado na sociedade de ordens do Antigo Regime}

Além de denotar a totalidade do corpo político em sua relação com o poder real, a mesma palavra povo também era o terceiro estado da sociedade de ordens do Antigo Regime, aquele que tinha o dever e o "direito" ao trabalho, ao lado da nobreza e do clero, de acordo com a tripartição da sociedade teorizada por São Tomaz de Aquino no século XI.

No decorrer das transformações econômicas e sociais postas em curso a partir das grandes navegações e dos processos de colonização, notadamente, a partir do século XVIII, surgiram inúmeros novos grupos sociais, o que acelerou um processo crescente que Antônio Manuel Espanha chamou de "pluralização de estamentos", que abalou esta tripartição tradicional. A visão da sociedade, que sempre tivera um caráter simplificador, o que fora percebido mesmo pelos teóricos medievais, se tornava bastante mais complexa com as transformações em direção à modernidade. Surgia um grupo intermediário entre o povo - os "mecânicos", como eram chamados no mundo luso - e os nobres: os burgueses, os letrados, os lentes das universidades, os advogados, os cirurgiões, os grandes comerciantes, de modo que a definição de quem é o povo passa a ser mais complexa. Embora formalmente fizessem parte do povo, não se adequavam bem ao qualificativo de "mecânicos". No interior do povo, cada vez mais passaram a haver os vis (ou plebe) e os limpos, isto é, aqueles dignos de alguma participação na sociedade e aqueles indignos por condição social, tipo de ocupação ou origem de sangue.

Os territórios coloniais portugueses constituíram o local onde este processo de dissolução ou complexificação na demarcação das três ordens tradicionais foi mais evidente. 0 professor régio Luis dos Santos Vilhena, famoso na historiografia pela sua frase "não é das menores desgraças viver em colônias"31, expôs bem este sentimento de dissolução e desagregação que tanto incomodava os observadores. Em suas cartas datadas nos anos iniciais do século XIX, analisa os prejuizos causados pela introdução de negros escravos, especialmente no que diz respeito aos costumes. Explica que

como todas as obras servis e artes mechanicas são manuzeadas por elles, poucos são os mulatos e raros brancos que nellas se querem empregar, sem exceptuar aquelles mesmos indigentes, que em Portugal nunca passarão de Criados de servir, de moçõs de taboa, e cavadores de enxada 32.

É certo, continua ele, que havia no Brasil daquela época familias nobres, mas "a duração dos tempos tem feito sensivel confusão entre nobres e abjetos plebeos" 33. Com essa "confusão", muitos indivíduos, "tendo seus pais vindo não há muitos anos para o Brazil para serem caixeiros, quando tivesses a capacidade de o ser, porque a fortuna thes foi propícia (...) cuidam seus filhos que o Imperador da China he digno de ser seu criado" 34. Esta "mania de ser nobre" seria mais grave nos mulatos, por sua condição ainda mais indefinida. Quase todos eles "querem ser Fidalgos, muitos fôfos e soberbos, e pouco amigos dos brancos e dos negros, sendo differentes as causas" 35 Devido ao que Vilhena considera uma, ou uma "quimérica nobreza",

o comum do povo he serem todos ociosos, não trabalhando a maior parte dos artífices, enquanto Ihes dura o comer a tempo que querendo apurar-se são em extremo habilidozos. 0 ordinário he serem conviventes e folgazões, e do comum bons homens 36 . 
37

SCHWARTZ, Stuart. Gente da Terra Braziliense da Nasção Pensando o Brasil: a Construção de um Povo. In: C. G. Mota (org.). Viagem Incompleta. A Experiência Brasileira (15002000). Formação: Histórias. São Paulo: Editora Senac, 2000

38

MELLO, Evaldo Cabral de. A fronda dos mazombos. Nobres contra mascates. Pernambuco 1666-1715. São Paulo: Editora 34, 2003. p.302.

39

Ibidem.

40

Ibidem.

\section{1}

COUTO, Domingos de Loreto. Desagravos do Brasil e Glórias de Pernambuco. Rio de Janeiro: Officina Typographica da Biblioteca Nacional, 1904.
Segundo Schwartz, no século XVIII, autoridades coloniais apontavam o problema de que nos territórios coloniais do Brasil não havia um povo propriamente dito. As tradicionais instituições representativas portuguesas - as cortes - nunca haviam sido instituídas na colônia e o conceito de "povo" como terceiro estado na sociedade de ordens, isto é, organicamente e constitucionalmente vinculado ao corpo da política, era frágil ou ausente em decorrência do tipo de ocupação "mecânica", do sangue impuro e dos costumes da população. Por isso, segundo o autor, o termo "plebe" ou o povo no sentido de plebe (povo miúdo, vulgo, canalha) passou a ser cada vez mais utilizado pelas autoridades coloniais em referência à população da colônia. 37

Ao tentar definir o que era esta plebe, autoridades coloniais recorriam muitas vezes a exemplos do passado greco-romano. Analisar a realidade através da história clássica era uma característica do modo de se produzir conhecimento sobre o mundo humano daquele momento, ainda profundamente marcado por uma concepção que podemos denominar de "história mestra da vida". Porém, podemos identificar neste recurso um esforço realizado pelas autoridades coloniais para entender as características impares de um mundo em que as formas costumeiras e tradicionais de demarcação social pareciam mais confundidas.

Era, porém, difícil para os observadores do periodo ter uma apreciação clara do conteúdo significativo da vasta plebe colonial. Reportando-se aos acontecimentos da guerra dos mascates em Pernambuco na primeira década do setecentos, Evaldo Cabral de Mello também percebeu que "as crônicas coevas designavam a população livre e pobre por 'plebe', a fim de distinguí-la do 'povo', noção mais abrangente que incluía as camadas médias, como os mascates (...) 38. Porém, não a descrevem de fato, "não só por preconceito elitista, mas até pela miopia ideológica que não thes permite definir-Ihe os contornos" 39 . Esta cegueira fica evidente nos Desagravos em que o tema é tratado em poucos parágrafos em que é evocada a plebe da antiguidade clássica, "a qual terá de retoricamente invocar para preencher a ausência da outra, a plebe colonial" 40.

Nas páginas dos Desagravos, Couto escreve que "sendo a nobreza a alma de uma republica, o seu corpo se compõe de homens mecânicos, assim chamados das artes mecânicas, ou servis, (...), e de povo miúdo, que é a gente popular, plebe e povo". Após esta introdução, parte o autor para Platão, que compara a plebe "a um grande animal, do qual é preciso conhecer as manhas para saber como há de ser tratado, que se não tem este animal quem o amanse, faz-se furioso, se não o guiam, não sabe para onde anda, é terrivel se não tem medo, começando a temer se perturba e foge". Além disso, "é incapaz de distinguir as aparências das verdades e quando falam de política, confundem as coisas, de modo que não podem governar a si próprios". Cita ainda Scipião, para quem "o vulgo era como o mar imóvel por sua natureza, mas segundo os ventos, que o agitam, quieto ou proceloso", e Catão, para quem "o "vulgo era como uma 'carneirada", pois "que assim como nenhum carneiro obedece a pessoa alguma, mas todos juntos seguem o mesmo pastor" 41.

No Discurso Histórico e Político sobre a Sublevação que houve nas Minas no ano de 1720, D. Pedro Miguel de Almeida Portugal, o Conde de Assumar, a quem se atribui a obra, percebia que os representantes da coroa portuguesa viviam nos territórios coloniais ameaçados por habitantes hostis e insubmissos, prontos a motins, tumultos e desordens. Assim como no escrito de Loreto Couto, o "povo", utilizado aqui no sentido de plebe, era 
42

Discurso Histórico e Político sobre a Sublevação que houve nas Minas no ano de 1720. Belo Horizonte: Fundação João Pinheiro, 1994. p.62.

43

Ibidem. p.73

44

Relatório do Marques do Lavradio. Apud. SOUZA, Laura de Mello e. Desclassificados do Ouro. A Pobreza Mineira no Século XVIII. Rio de Janeiro: Edições Graal, 1986. p.106.

45

Ibidem. p.109. descrito através de exemplos da autoridade clássica. Para o conde, a situação vivida na colônia era um espelho do que havia ocorrido na criação de Roma, de acordo com a descrição legada por Lucio Floro "o povo constava de varões que não tinham mais bens que a esperança do que houvessem de conquistar suas armas, roubando" 42. Em outra passagem, cita a descrição de Tertuliano sobre os habitantes do Ponto Euximo: "uma região habitada por gente intratável, sem domicilio, e ainda que está em contínuo movimento". Analisar a realidade através da história clássica era uma caracteristica do modo de se produzir conhecimento sobre o mundo humano daquele momento, ainda profundamente marcado por uma concepção que podemos denominar de "história mestra da vida". Porém, podemos identificar neste recurso um esforço realizado pelas autoridades coloniais para entender as características impares de um mundo em que as formas costumeiras e tradicionais de demarcação social pareciam mais confundidas.

Outra marca presente no Discurso e nos Desagravos é a concepção de que a "plebe" ou o "vulgo" não tem motivações e atuação políticas próprias, sendo apenas levada pela vontade de alguns principais. Para Loreto Couto, a plebe é incapaz de governar a si própria, tal qual os carneiros que seguem o pastor e o mar que muda conforme os ventos. 0 Conde de Assumar, assinala o mesmo, ao afirmar que "tal é a natureza do vulgo, que para se alegrar e folgar com o seu próprio mal, basta ser novidade e sem razão, porque tem, como por hombridade e capricho, seguir tudo o que vem contra a razão, contra a piedade e contra o agradecimento" 43 A "ínfima plebe" só se envolve em amotinações quando levada pelos "cabeças". As pessoas envolvidas nos movimentos rebeldes das minas são de duas qualidades: aqueles que desejam dominar o governo, recuperar ou manter seus antigos privilégios, e a plebe desejosa apenas de se ver livre das dividas e da punição por seus crimes. Este "perdido gado" deve o quanto antes voltar ao seu "pastor", pois sem ele vai "mal guiado".

Laura de Melo e Souza, no seu conhecido Desclassificados do Ouro assinalou o problema que significou para as autoridades coloniais a manutenção desta plebe colonial nos limites da ordem e a falta de um verdadeiro "povo". No período da produção aurifera nas Minas, houve, segundo a autora, um inédito ajuntamento populacional na região, tornando ainda mais premente a preocupação das autoridades. A urbanização na região das minas trouxe como conseqüência a convivência entre populações de forma muito mais íntima que em qualquer outro ponto da colônia. Daí que normalizar a população e cobrar impostos tornaram-se necessidades prementes. A população de escravos, indios e forros representava um grave problema. Temia-se uma revolta escrava, e também o agravamento das revoltas fiscais que se proliferaram no setecentos.

As autoridades portuguesas, que para lá eram mandadas em grande número, apontavam, como fez o Marques do Lavradio, que aqueles povos eram "gentes da pior educação, de um caráter o mais libertino, como são negros, mulatos, cabras, mestiços e outras gentes semelhantes" tornavam impossível o exercício do governo" 44. Daí a "ideologia da vadiagem": a população livre e pobre era considerada vadia e deveria ser rapidamente enquadrada em uma forma de trabalho. Urgia aplicar, segundo o Conde de Assumar em 1718, "os Remédios Violentos, como tão preciosos, a uma canalhada tão indômita" 45

A distinção entre nobres e não nobres, bem como entre povo e plebe permaneceu fundamental nos principais movimentos ocorridos na segunda 
46

MAXWEL, Kenneth. A Devassa da Devassa. Rio de Janeiro: Paz e Terra, 2001.
47

Sobre esta questão ver MONNIER, Raymonde. Autour des usages d'un nom indistinct: 'peuple' sous la Révolution Française. Révue DixHuitième Siècle, 34, 2002. p.389-418; e também FRITZ, Gerard. L'idée de Peuple em France du XVIle au XVIIle siècle. Presses Universitaires de Strasburg, 1988.

\section{8}

XAVIER, Ângela Barreto e HESPANHA, António Manuel. A Representação da Sociedade e do Poder. Paradigmas Políticos e Tradiçoes Literárias. In. HESPANHA, A. M. (coord.). História de Portugal. Vol. 4. 0 Antigo Regime. Lisboa: E. Estampa, 1993. metade do século XVIII e início do XIX. No movimento mineiro de 1789, composto basicamente por membros da elite urbana nascente, padres e intelectuais, embora se conclamasse genericamente o "povo" para participar da luta contra a tirania, não se viu o povo pobre e mestiço, a plebe, como participante legítimo da nova sociedade a ser criada. A concepção estamental de sociedade ainda prevalecia sobre a de igualdade civil e política. Os conspiradores tinham no horizonte proclamar uma republica nos moldes norte-americanos com um povo composto de proprietários e ilustrados. Era, segundo Maxwell, sobretudo "um movimento de oligarcas e no interesse da oligarquia, sendo o nome do povo evocado apenas como justificativa" 46.

\section{Considerações Finais}

No século XVIII luso-brasileiro, o conceito de povo, embora tenha permanecido nos marcos da tradição política, teve seu significado em grande medida reinventado. As contingências da vida em colônia e os primeiros ares da modernidade começavam a abalar a estabilidade das concepções políticas vigentes. A noção de pacto ganhou muitas vezes maior radicalidade, com o direito de rebelião dos povos frente ao despotismo vindo a primeiro plano. Ao mesmo tempo, percebia-se cada vez mais claramente a artificialidade da tripartição em três ordens - clero nobreza e povo - num mundo marcado pela escravidão, pela convivência de raças não brancas num espaço econômico e social amplamente diverso do europeu. As distinções se fluidificavam e complexificavam, tornando o conceito de povo sinônimo ou substituivel pelas expressões plebe, vulgo, povo miúdo.

A força da tradição no uso e semântica do conceito de povo mesmo nas grandes conspirações do final do século não significa o malogro do liberalismo ou um "liberalismo peculiar" ao mundo ou luso-brasileiro, que não soubera generalizar uma sociedade de cidadãos livres e iguais. Mesmo na Europa ilustrada, a concepção de um povo de iguais era difícil nestes primórdios no mundo contemporâneo, ainda fortemente imerso nas práticas e idéias do Antigo Regime. ${ }^{47}$.

Se a idéia de um povo de indivíduos iguais em direitos civis e políticos era muito frágil nos movimentos liberais de finais do XVIII e inícios do XIX em países como a França, no mundo português e brasileiro do Antigo Regime, o peso e a permanência da tradição estamental corporativa era particularmente notável${ }^{48}$, especialmente no espaço colonial, muito fechado ao contato com o mundo europeu.

0 fato de o mundo estar passando por amplas transformações intelectuais, sociais e políticas, com as revoluções americana e francesa e a ilustração, não implica um reflexo direto destas no espaço luso-americano. A análise da linguagem política dos agentes mostra que para além de uma "influência" de idéias estrangeiras, os movimentos de contestação contaram com um repertório de crítica ao despotismo e de defesa de direitos próprios ao antigo regime português. Isso não implica um pressuposto de imobilidade da história, de que as mudanças eram impossiveis dado o peso das tradições. As próprias tradições, como vimos, podiam ganhar contornos de radicalização e foram veiculadas e defendidas em determinados contextos de crise, como em Pernambuco em 1817. Não podemos esquecer que de fato, houve momentos em que o povo ganhou significados em grande medida já afastados da tradição, como na Bahia de 1798.

Será o povo no século XVIII um conceito propriamente? A história de um conceito se quiser fugir ao historicismo ingênuo da tradicional história 
das idéias, deve renunciar a tentativas de seguir uma linha de evolução do conceito "passando pelas suas diversas épocas históricas". Esta démarche tem por base uma visão essencialista das idéias e conceitos, atribuindoIhes uma substância fixa e a-histórica, que se manifestaria de maneiras diferentes em seus estágios de desenvolvimento e maturação. É preciso, então questionar a propriedade de se falar em "conceito de povo no século XVIII". A política pensada em termos de um campo discursivo formado por conceitos é uma criação do mundo moderno, assim como a vivência de um amplo espaço público de debate político. No caso específico do conceito de que estamos tratando, é importante não perder de vista que sua centralidade no debate político é, sobretudo, um fenômeno contemporâneo, a partir da generalização da idéia de soberania popular. Embora se falasse em "povo" desde os primórdios da colonização, não acredito que o povo fosse de fato um conceito. Seu significado é inextricavelmente ligado à relação com a figura real, não tendo contornos próprios e definidos, um conteúdo especifico e fundamentado. A palavra povo, além disso, podia ser substituída por outras expressões intercambiáveis (os vassalos, os súditos, a comunidade, os mecânicos e outros).

Embora a idéia de povo estivesse ganhando maior relevância ao longo do século XVIII - na verdade, desde o século XVII com as doutrinas pactistas da Segunda Escolástica - o seu conteúdo significativo era pouco questionado. A tradição ibérica e também, de modo mais geral, a tradição ocidental forneciam os elementos de seu significado. 0 debate sobre quem é o povo, quais suas características, suas potencialidades, sua composição, praticamente inexistia. Sua existência era apenas considerada em função de sua relação com o monarca, não tendo um significado inerente e particular. As poucas tentativas de defini-lo de forma direta e específica levavam quase sempre à evocação do passado greco-romano ou ao texto bíblico, evidenciando, além de uma cegueira elitista, o fato de que o povo não havia ainda se tornado um conceito imerso no debate político, o que ocorreria no século XIX. 